\title{
FAKTOR-FAKTOR YANG MEMPENGARUHI KELENGKAPAN IMUNISASI DASAR BAYI DI POSYANDU BALITA KALINGGA KELURAHAN BANYUANYAR SURAKARTA
}

\author{
Nur Rakhmawati ${ }^{1}$, Ratih Dwilestari Puji Utami ${ }^{2}$, Innez Karunia Mustikarani ${ }^{3}$ \\ Sarjana Keperawatan dan Profesi Ners, Universitas Kusuma Husada Surakarta \\ nurrakhmawati ikmuns@yahoo.co.id
}

\begin{abstract}
Abstrak
Pendahuluan: Imunisasi merupakan suatu strategi yang efektif dan efisien dalam meningkatkan derajat kesehatan nasional. Cakupan kelengkapan imunisasi dasar pada bayi masih terdapat anak-anak yang sama sekali belum mendapatkan imunisasi atau belum lengkap imunisasinya. Imunisasi Dasar Lengkap (IDL) di Indonesia mencapai 86,8\%, dan perlu ditingkatkan hingga mencapai target $93 \%$ di tahun 2019. Universal Child Immunization (UCI) desa yang kini mencapai $82,9 \%$ perlu ditingkatkan hingga mencapai 92\% di tahun 2019.

Tujuan: Penelitian ini bertujuan untuk mendeskripsikan faktor-faktor yang mempengaruhi kelengkapan imunisasi dasar bayi

Metode: Penelitian ini merupakan penelitian analitik observasional dengan pendekatan cross sectional. Pengambilan sampel dilakukan secara consecutive sampling dengan analisis yang digunakan regresi logistik ganda. Populasi penelitian ini adalah ibu yang memiliki bayi usia $\geq 12-18$ bulan dan berkunjung ke posyandu balita yang berjumlah 25 orang. Analisis data yang digunakan adalah analisis data bivariat dengan menggunakan chi square dan data multivariat menggunakan regresi logistik ganda.

Hasil: Tidak ada pengaruh pekerjaan dengan kelengkapan imunisasi dasar bayi dengan $p$ value sebesar 0,848>0,05. Tidak ada pengaruh pendidikan dengan kelengkapan imunisasi dasar dengan $p$ value sebesar $0,775>0,05$. Ada pengaruh pengetahuan dengan kelengkapan imunisasi dasar bayi dengan $p$ value sebesar $0,037<0,05$. Tidak ada pengaruh sikap dengan kelengkapan imunisasi dasar bayi dengan $p$ value sebesar 0,595 > 0,05 . Ada pengaruh motivasi dengan kelengkapan imunisasi dasar bayi dengan $p$ value sebesar $0,046<0,05$.

Kesimpulan: Faktor yang paling berpengaruh adalah motivasi dengan kelengkapan imunisasi dasar, nilai Odd Ratio sebesar 20,091 berarti bahwa ibu yang mempunyai motivasi baik memiliki kemungkinan 20,091 lebih besar untuk melakukan imunisasi dasar bayi secara lengkap dibandingkan dengan ibu yang memiliki motivasi tidak baik.
\end{abstract}

Kata Kunci: Pekerjaan, Pendidikan, Pengetahuan, Sikap, motivasi dan kelengkapan imunisasi dasar

\footnotetext{
Abstract

Background: Immunization is an effective and efficient strategy in improving national health status. However, there are still many children who have not received any immunizations or incomplete immunizations in term of the complete basic immunization coverage. Complete Basic Immunization (CBI) in Indonesia reaches $86.8 \%$, and needs to be increased to get $93 \%$ target in 2019. Meanwhile, Universal child immunization (UCI) in villages which now reaches $82.9 \%$, needs to be increased to get $92 \%$ target in 2019 .

Objective: This study aims to describe the factors that influence the completeness of basic infant immunization.
} 
Method: This study is an observational analytic study with a cross sectional approach. Sampling is done by consecutive sampling with the analysis using multiple logistic regression. The population of this study was 25 mothers who have babies aged between 12 to18 months and have visited the posyandu (integrated health service post for toddlers). Analysis of the data used is bivariate data analysis using chi square and multivariate data using multiple logistic regression.

Results: There is no influence of occupational background with the basic completeness of infant immunization with a $\mathrm{p}$ value of $0.848>0.05$. There is no influence of educational background with basic immunization completeness with a $\mathrm{p}$ value of $0.775>0.05$. There is an influence of knowledge with the basic completeness of infant immunization with a $\mathrm{p}$ value of $0.037<0.05$. There is no influence of attitude with the completeness of basic immunization for infants with a $\mathrm{p}$ value of $0.595>0.05$. There is a motivational influence on the completeness of basic infant immunization with a p value of $0.046<0.05$.

Conclusion: The most influential factor is motivation of 20,091.

Keywords: Occupational background, Educational background, Knowledge, Attitude, motivation and basic immunization completion

\section{Pendahuluan}

Kematian bayi baru lahir disebabkan oleh berbagai bentuk infeksi seperti infeksi saluran napas, tetanus neonatorum, sepsis, meningitis, dan infeksi gastrointestinal. Penyebab kematian bayi yang lainnya adalah berbagai penyakit yang sebenarnya dapat dicegah dengan imunisasi, seperti tetanus, campak, dan difteri. Anggota WHO sebanyak 194 negara, 65 diantaranya memiliki cakupan imunisasi Difteri, Pertusis dan Tetanus (DPT) di bawah target global 90\%. Upaya untuk menghapus kantong-kantong wilayah dimana banyak anak- anak tidak terlindungi dari penyakit yang sebenarnya dapat dicegah melalui imunisasi. Menurut Organisasi Kesehatan Dunia (WHO), pada tahun 2018 ada sekitar 20 juta anak di dunia yang tidak mendapatkan imunisasi lengkap, bahkan ada yang tidak mendapatkan imunisasi sama sekali. Padahal Untuk mendapatkan kekebalan komunitas (herd Immunity) dibutuhkan cakupan imunisasi yang tinggi (paling sedikit 95\%) dan merata. Akan tetapi, saat ini masih banyak anak Indonesia yang belum mendapatkan imunisasi lengkap. Bahkan ada pula anak yang tidak pernah mendapatkan imunisasi sama sekali sejak lahir.

Data dari Direktorat Pencegahan dan Pengendalian Penyakit, Kementerian Kesehatan (Kemenkes) RI menunjukkan sejak 2014-2016, terhitung sekitar 1,7 juta anak belum mendapatkan imunisasi atau belum lengkap status imunisasinya. Indonesia, Imunisasi Dasar Lengkap (IDL) mencapai 86,8\%,dan perlu ditingkatkan hingga mencapai target 93\% di tahun 2019. Universal Child Immunization (UCI) desa yang kini mencapai $82,9 \%$ perlu ditingkatkan hingga mencapai $92 \%$ di tahun 
2019. Di tingkat nasional, kita mengharapkan target Imunisasi Dasar Lengkap 91\% dan UCI Desa 84\%( Kemenkes RI, 2017). Sementara tahun ini terhitung Januari hingga Maret imunisasi dasar lengkap mencapai 13,9\%, dan imunisasi DPT-HBHib Baduta mencapai 10,8\%. Target cakupan imunisasi dasar lengkap 2018 sebesar 92,5\% dan imunisasi DPT-HB-Hib Baduta 70\% (Kemenkes RI, 2018).

Imunisasi diakui secara global telah berhasil menurunkan berbagai infeksi seperti difteri, batuk rejan, tetanus, campak, hepatitis B, meningitis dan pneumonia yang disebabkan oleh haemophilus influenza tipe $B(H i b)$, justru penyakit cacar (variola) telah musnah dari muka bumi akibat semua orang telah di imunisasi cacar. Harapan terbuka lebar dalam waktu dekat penyakit poliomielitis akan tidak dapat dijumpai lagi di seluruh dunia. Pentingnya pemberian imunisasi dapat dilihat dari banyaknya balita yang meninggal akibat penyakit yang dapat dicegah dengan imunisasi. Oleh karena itu, untuk mencegah balita menderita beberapa penyakit yang berbahaya imunisasi pada bayi dan balita harus lengkap serta diberikan sesuai jadwal. Tujuan diberikan imunisasi adalah harapan anak menjadi kebal terhadap penyakit sehingga dapat menurunkan angka morbiditas dan mortalitas serta dapat mengurangi kecacatan akibat penyakit tertentu (Mulyani, 2018).

Berdasarkan hasil penelitian Prihanti, Rahayu dan Abdullah (2016), Terdapat pengaruh signifikan antara usia, pekerjaan, pengetahuan, kehadiran balita terhadap status kelengkapan imunisasi dasar di Di Wilayah Kerja Puskesmas X Kota Kediri tetapi untuk faktor pendidikan, pendapatan, sikap, dan peran petugas kesehatan tidak mempengaruhi status kelengkapan imunisasi dasar di Di Wilayah Kerja Puskesmas X Kota Kediri. Hasil penelitian yang dilakukan Istriyati (2011) dengan judul Faktor-Faktor Yang Berhubungan Dengan Kelengkapan Imunisasi Dasar Pada Bayi Di Desa Kumpulrejo Kecamatan Argomulyo Kota Salatiga, hasil penelitiannya ada hubungan antara tingkat pendidikan, pengetahuan, pekerjaan, dukungan keluarga dengan Kelengkapan Imunisasi Dasar Pada Bayi Di Desa Kumpulrejo Kecamatan Argomulyo Kota Salatiga tetapi untuk faktor tingkat pendapatan keluarga, jumlah anak dalam keluarga, keterjangkauan tempat imunisasi tidak ada hubungan dengan Kelengkapan Imunisasi Dasar Pada Bayi Di Desa Kumpulrejo Kecamatan Argomulyo Kota Salatiga.

Fenomena yang terjadi saat ini adalah berdasarkan studi pendahuluan pada tanggal 9 Januari 2019 didapatkan bahwa kurangnya sarana informasi tentang imunisasi karena belum dilakukan kunjungan rumah untuk melengkapi status 
imunisasi, sebagian orangtua menolak anaknya untuk diimunisasi dikarenakan kepercayaan agama dan lain-lain. Berdasarkan latar belakang di atas, penulis tertarik untuk melakukan penelitian tentang "Faktor-Faktor Yang Mempengaruhi Kelengkapan Imunisasi Dasar Bayi Di Posyandu Balita Kalingga Kelurahan Banyuanyar Surakarta”.

\section{Tujuan}

Penelitian ini bertujuan untuk mendeskripsikan faktor-faktor yang mempengaruhi kelengkapan imunisasi dasar bayi di Posyandu Balita Kalingga.

\section{Metode}

Penelitian ini merupakan penelitian analitik observasional dengan pendekatan cross sectional. Pengambilan sampel dilakukan secara consecutive sampling. Kriteria inklusi meliputi Ibu yang mempunyai bayi usia $\geq 12-18$ bulan, Ibu yang hadir ke posyandu Balita Banyuanyar dan bersedia menjadi responden penelitian. Kriteria eksklusi meliputi: Ibu yang anaknya telah berusia > 19 bulan, tidak memahami bahasa Indonesia dan tidak melengkapi data angket. Penelitian ini dilakukan di Posyandu Balita Kalingga Kelurahan Banyuanyar Surakarta, pada bulan April 2019. Populasi penelitian ini adalah ibu yang memiliki bayi usia $\geq 12$ - 18 bulan dan berkunjung ke posyandu balita Kalingga Banyuanyar Surakarta yang berjumlah 25 orang. Pada penelitian ini menggunakan alat pengumpul data berupa kuesioner. Analisis data yang digunakan adalah analisis data bivariat dengan menggunakan chi square dan data multivariat menggunakan regresi logistik ganda. 


\section{Hasil}

Tabel 1 Karakteristik Responden

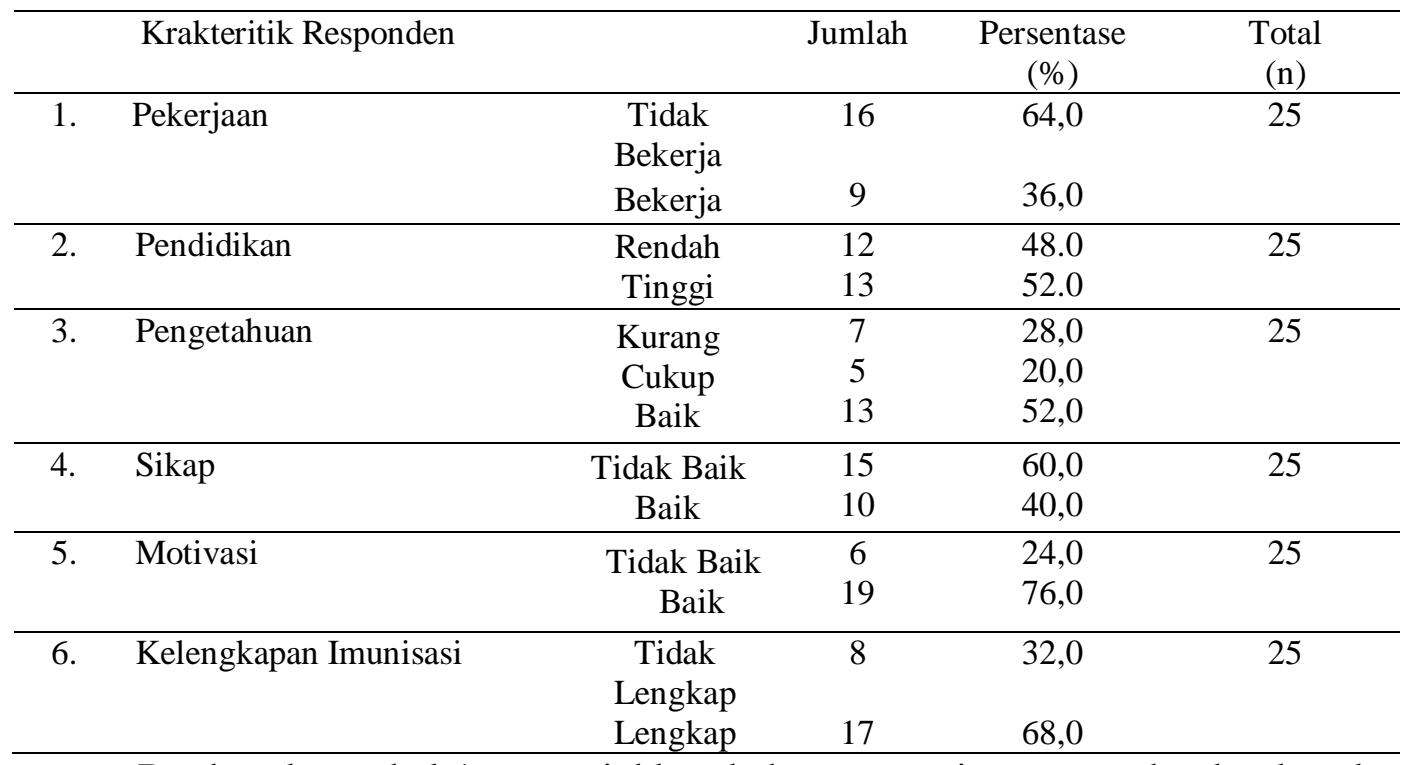

Berdasarkan tabel 1 menunjukkan bahwa mayoritas responden berdasarkan pekerjaan adalah tidak bekerja yaitu sebanyak 16 responden (64,0\%). Mayoritas pendidikan responden adalah pendidikan tinggi yaitu sebanyak 13 responden $(52,0 \%)$. Mayoritas pengetahuan responden adalah pengetahuan yang baik yaitu sebanyak 13 responden (52,0\%). Mayoritas sikap responden adalah sikap yang tidak baik yaitu sebanyak 15 responden $(59,4 \%)$. Mayoritas motivasi responden adalah motivasi yang baik yaitu sebanyak 19 responden (76,0\%). Mayoritas kelengkapan imunisasi responden adalah imunisasi yang lengkap yaitu sebanyak 17 responden $(68,0 \%)$.

Tabel 2 Faktor-faktor yang Mempengaruhi Kelengkapan Imunisasi Dasar Bayi

\begin{tabular}{lcccc}
\hline \multicolumn{1}{c}{ Variabel } & Exp (B) & \multicolumn{2}{c}{ CI 95\% } & p Uji \\
\cline { 3 - 4 } & $($ OR) & Batas bawah & Batas atas & Wald \\
\hline Pekerjaan & .739 & .033 & 16.469 & .848 \\
Pendidikan & .670 & .043 & 10.460 & .775 \\
Pengetahuan & 5.607 & 1.106 & 28.420 & .037 \\
Sikap & 2.232 & .116 & 42.951 & .595 \\
Motivasi & 20.091 & 1.050 & 384.417 & .046 \\
N observasi & 25 & & & \\
-2 log likelihood & 16,03 & & & \\
Nagelkerke R ${ }^{2}$ & $64,1 \%$ & & & \\
\hline
\end{tabular}

a. Pengaruh pekerjaan dengan kelengkapan imunisasi dasar bayi

Nilai Odd Ratio variabel pekerjaan sebesar 0,739 berarti bahwa ibu yang bekerja mempunyai kemungkinan 0,739 kali lebih besar untuk melakukan imunisasi dasar bayi secara lengkap dibandingkan dengan ibu yang tidak 
bekerja. Hasil uji wald diperoleh diperoleh nilai dengan $p$ value sebesar 0,848 $>0,05$ artinya tidak ada pengaruh pekerjaan dengan kelengkapan imunisasi dasar bayi di Posyandu Balita Kalingga Banyuanyar Surakarta.

b. Pengaruh pendidikan dengan kelengkapan imunisasi dasar bayi

Nilai Odd Ratio variabel pendidikan sebesar 0,670 berarti bahwa ibu yang mempunyai pendidikan tinggi mempunyai kemungkinan 0,670 kali lebih besar untuk melakukan imunisasi dasar bayi secara lengkap dibandingkan dengan ibu yang mempunyai pendidikan rendah. Hasil uji wald diperoleh $p$ value sebesar $0,775>0,05$ artinya tidak ada pengaruh pendidikan dengan kelengkapan imunisasi dasar bayi di Posyandu Balita Kalingga Banyuanyar Surakarta.

c. Pengaruh pengetahuan dengan kelengkapan imunisasi dasar bayi

Nilai Odd Ratio variabel pengetahuan sebesar 5,607 berarti bahwa ibu yang tidak mempunyai pengetahuan baik memiliki kemungkinan 5,607 lebih besar untuk melakukan imunisasi dasar bayi secara lengkap dibandingkan dengan ibu yang memiliki pengetahuan kurang. Hasil uji wald diperoleh $p$ value sebesar $0,037<0,05$ artinya ada pengaruh pengetahuan dengan kelengkapan imunisasi dasar bayi di Posyandu Balita Kalingga Banyuanyar Surakarta.

d. Pengaruh sikap dengan kelengkapan imunisasi dasar bayi

Nilai Odd Ratio variabel sikap sebesar 2,232 berarti bahwa ibu yang mempunyai sikap baik mempunyai kemungkinan 2,232 kali lebih besar untuk melakukan imunisasi dasar bayi secara lengkap dibandingkan dengan ibu yang mempunyai sikap tidak baik. Hasil uji wald diperoleh $p$ value sebesar 0,595> 0,05 artinya tidak ada pengaruh sikap dengan kelengkapan imunisasi dasar bayi di Posyandu Balita Kalingga Banyuanyar Surakarta.

e. Pengaruh motivasi dengan kelengkapan imunisasi dasar bayi

Nilai Odd Ratio variabel motivasi sebesar 20,091 berarti bahwa ibu yang tidak mempunyai motivasi baik memiliki kemungkinan 20,091 lebih besar untuk melakukan imunisasi dasar bayi secara lengkap dibandingkan dengan ibu yang memiliki motivasi tidak baik. Hasil uji wald diperoleh $p$ value sebesar 0,046 < 0,05 artinya ada pengaruh motivasi dengan kelengkapan imunisasi dasar bayi di Posyandu Balita Kalingga Banyuanyar Surakarta. 


\section{Pembahasan}

Berdasarkan Tabel 1 dapat dilihat bahwa menurut karakteristik pekerjaan responden, bahwa mayoritas responden adalah tidak bekerja yaitu sebanyak 16 responden (64,0\%). Hasil ini menunjukkan bahwa ibu yang tidak bekerja memiliki waktu untuk berkumpul bersama anaknya lebih lama. Hasil ini sesuai dengan pernyataan dari Triana (2015) bahwa orang tua atau ibu yang tidak bekerja memiliki banyak waktu di rumah sehingga tidak ada alasan bagi mereka untuk tidak mengantarkan bayinya ke tempat pelayanan kesehatan agar diberikan imunisasi. Seseorang yang mempunyai pekerjaan dengan waktu yang cukup padat akan mempengaruhi ketidakhadiran dalam pelaksanaan posyandu. Seorang ibu yang tidak bekerja akan mempunyai kesempatan untuk mengimunisasikan anaknya dibanding dengan ibu yang bekerja. Zuriatina, dkk (2016) dikalangan ibu tidak bekerja sikap dan perilaku mereka tentang imunisasi lebih baik dibanding ibu yang bekerja. Dengan kata lain ibu yang tidak bekerja lebih sering membawa bayinya imunisasi, sehingga status imunisasi dasar pada bayinya lebih lengkap dibandingkan ibu yang bekerja.

Menurut karakteristik pendidikan responden, bahwa mayoritas responden mempunyai pendidikan tinggi yaitu sebanyak 13 responden (52,0\%). Ibu yang memiliki tingkat pendidikan tinggi pada dasarnya akan memiliki pengetahuan baik tentang imunisasi dasar lengkap bagi balitanya. Pendidikan merupakan salah satu faktor yang sangat penting dalam menentukan perilaku ibu, karena seorang ibu dengan berpendidikan tinggi akan mempengaruhi kesehatan keluarganya, sebab banyak informasi yang diperoleh di sekolah, tapi apabila seseorang berpendidikan rendah, maka diharapkan ia dapat menambah informasinya dari sumber lainnya di luar dari pendidikan formal atau disebut jalur informal seperti melalui media elektronik (televisi, radio, internet), membaca koran, atau majalah (Prihanti, dkk, 2016). Hal ini sesuai pernyataan dari Notoatmodjo (2014) bahwa pendidikan sangat penting bagi seseorang untuk meningkatkan kemampuan dalam berfikir, menelaah dan memahami informasi yang diperoleh dengan pertimbangan yang lebih rasional. Pendidikan yang baik akan memberikan kemampuan yang baik pula kepada seseorang dalam mengambil keputusan dalam hal kesehatan keluarga terutama imunisasi anak. Pendidikan secara umum merupakan segala upaya yang direncanakan untuk mempengaruhi orang lain, individu, kelompok, atau 
masyarakat sehingga mereka melakukan apa yang diharapkan oleh pelaku pendidikan.

Menurut karakteristik pengetahuan, bahwa mayoritas responden mempunyai pengetahuan yang baik tentang imunisasi yaitu sebanyak 13 responden $(52,0 \%)$. Pengetahuan merupakan tahap awal di mana ibu mulai mengenal ide baru serta belajar memahami yang pada akhirnya dapat mengubah perilaku. Semakin baik pengetahuan ibu tentang pemberian imunisasi maka akan memberikan respons yang positif yaitu meningkatkan kemauan ibu untuk memberikan imunisasi dasar pada bayi. Pengetahuan yang baik dapat mempengaruhi terjadinya perubahan perilaku. Perilaku dapat diubah dengan mengubah pengetahuan dan sikap. Pengetahuan yang baik dapat mempengaruhi sikap dan terjadinya perubahan perilaku. Pengetahuan adalah sesuatu yang perlu tetapi pada umumnya tidak cukup satu faktor dalam mengubah perilaku individu atau kelompok. Notoatmodjo (2014) menyatakan bahwa tindakan seseorang terhadap masalah kesehatan pada dasarnya akan dipengaruhi oleh pengetahuan seseorang tentang masalah tersebut.

Menurut karakteristik sikap, bahwa mayoritas responden mempunyai sikap yang tidak baik yaitu sebanyak 15 responden $(59,4 \%)$. Hal ini menunjukan bahwa dengan sikap yang tidak baik dari ibu terhadap imunisasi disebabkan karena imunisasi dilakukan dalam jangka panjang sehingga ibu harus memahami jadwalnya dengan baik. Sikap merupakan respon seseorang yang masih tertutup terhadap suatu stimulus atau objek. Pengetahuan, pikiran, keyakinan, dan emosi memegang peranan penting dalam penentuan sikap seseorang (Notoatmodjo, 2014). Sikap responden dalam penelitian ini meliputi kenyamanan ibu saat anak diimunisasi, kenyamanan ibu setelah anak diimunisasi, sikap ibu tentang efek dari imunisasi, padangan agama (halal/haram) pemberian imunisasi. Faktor yang mempengaruhi banyaknya responden yang memiliki sikap negatif tentang imunisasi adalah pengetahuan yang rendah tentang imunisasi, semakin rendah pengetahuan ibu tentang imunisasi maka akan memberikan kontribusi yang besar terhadap pembentukan sikap yang kurang baik/negatif tentang imunisasi (Triana, 2015).

Menurut karakteristik motivasi, bahwa mayoritas responden mempunyai motivasi yang baik yaitu sebanyak 19 responden $(76,0 \%)$. Hasil ini menunjukkan bahwa ibu akan berinteraksi melalui rangsangan yang diterima dari dirinya sendiri atau dari lingkungan sekitarnya sehingga termotivasi untuk melakukan imunisasi 
dasar lengkap pada balitanya. Hal ini sejalan dengan theory of planned behavior yang dimana menyatakan bahwa salah satu penunjang seseorang melakukan suatu perilaku adalah dengan motivasi (Hilda, 2017). Ibu yang mempunyai pekerjaan itu demi mencukupi kebutuhan keluarga (kebutuhan pertama) akan mempengaruhi kegiatan imunisasi yang termasuk kebutuhan rasa aman dan perlindungan sehingga ibu lebih mengutamakan pekerjaan dari pada mengantarkan bayinya untuk di imunisasi (Prihanti, dkk, 2016).

Menurut karakteristik kelengkapan imunisasi dasar bayi, bahwa mayoritas responden memperoleh imunisasi yang lengkap yaitu sebanyak 17 responden (68,0\%). Kemenkes RI (2017) menyatakan bahwa imunisasi merupakan salah satu upaya untuk merangsang sistim imunologi tubuh untuk membentuk antibodi (kekebalan) yang spesifik sehingga dapat melindungi tubuh dari serangan (Penyakit yang Dapat Dicegah Dengan Imunisasi, PD3I). Kepercayaan dan perilaku kesehatan ibu juga hal yang penting karena akan mempengaruhi status imunisasi anak. Pelayanan imunisasi dasar lengkap diberikan oleh petugas Puskesmas antara lain imunisasi BCG, DPT, polio, dan campak. Cakupan imunisasi dasar lengkap di Posynadu dikarenakan beberapa faktor seperti pengetahuan dan motivasi ibu. Scobie et al (2015) menjelaskan cakupan imunisasi dikarenakan beberapa alasan, antara lain adalah pengetahuan ibu terhadap imunisasi, serta kesadaran akan pentingnya kebutuhan imunisasi. Kelengkapan dalam pemberian imunisasi dikatakan lengkap jika balita mendapatkan imunisasi sesuai dengan jenis dan jadwal yang ditetapkan. Hasil penelitian menunjukkan bahwa masih terdapat status imunisasi bayinya tidak lengkap $(32,0 \%)$ yang kemungkinan ada beberapa faktor yang mempengaruhi yaitu ibu meragukan keamanan dari vaksin dan banyak ibu yang tidak mengetahui frekuensi pemberian masing-masing imunisasi.

Tabel 2 menunjukkan pengaruh pekerjaan dengan kelengkapan imunisasi dasar bayi, bahwa tidak ada pengaruh pekerjaan dengan kelengkapan imunisasi dasar bayi di Posyandu Balita Kalingga Banyuanyar Surakarta $(0,739>0,05)$. Hasil ini mendukung penelitian terdahulu dari Rahmawati dan Umbul (2014) yang menyatakan bahwa tidak terdapat adanya pengaruh antara status pekerjaan terhadap ketidaklengkapan status imunisasi pada bayi atau balita. Tidak adanya pengaruh ini dikarenakan terdapat kesamaan antara responden yang memiliki anak dengan status imunisasi lengkap maupun tidak lengkap yang sebagian besar tidak bekerja atau hanya sebagai ibu rumah tangga. Ibu yang bekerja memiliki waktu luang yang 
sedikit bila dibandingkan dengan ibu yang tidak bekerja, sehingga pada ibu yang bekerja biasanya kelengkapan imunisasi akan lebih sulit dilakukan daripada ibu yang tidak bekerja. Hal tersebut menunjukkan bahwa pekerjaan ibu dapat berdampak pada kelengkapan imunisasi anaknya, karena pada ibu yang tidak bekerja memiliki waktu luang yang lebih banyak dibandingkan ibu yang bekerja, sehingga ibu yang tidak bekerja memiliki peluang yang lebih besar untuk kelengkapan imunisasi pada anaknya (Zuriatina, dkk, 2016).

Tabel 2 menunjukkan pengaruh pendidikan dengan kelengkapan imunisasi dasar bayi, bahwa tidak ada pengaruh pendidikan dengan kelengkapan imunisasi dasar bayi di Posyandu Balita Kalingga Banyuanyar Surakarta $(0,775>0,05)$. Hasil penelitian ini mendukung penelitian terdahulu dari Prihanti, dkk (2016) yang menyatakan bahwa tidak ada hubungan antara pendidikan terhadap kelengkapan imunisasi. Hal ini dikarenakan distribusi ibu dengan tingkat pendidikan yang tinggi dan rendah tidak mempunyai pengaruh terhadap kelengkapan imunisasi dasar bayi. Tingkat pendidikan menggambarkan tingkat kematangan seseorang dalam merespon lingkungan sehingga dapat mempengaruhi wawasan berpikir atau merespon pengetahuan yang ada di sekitarnya. Semakin tinggi tingkat pendidikan seseorang maka semakin besar peluang untuk mendapatkan informasi yang dapat mempunyai pengertian lebih baik tentang pencegahan penyakit dan mempunyai kesadaran lebih tinggi terhadap masalah-masalah kesehatan (Rahmawati dan Umbul, 2014).

Tabel 2 menunjukkan pengaruh pengetahuan dengan kelengkapan imunisasi dasar bayi, bahwa ada pengaruh pengetahuan dengan kelengkapan imunisasi dasar bayi di Posyandu Balita Kalingga Banyuanyar Surakarta $(0,037<0,05)$. Hasil ini mendukung penelitian dari Prihanti, dkk (2016) bahwa pengetahuan Ibu mempengaruhi status kelengkapan imunisasi dasar pada bayi. Pengetahuan merupakan tahap awal di mana subjek mulai mengenal ide baru serta belajar memahami yang pada akhirnya dapat mengubah perilaku. Semakin baik pengetahuan ibu tentang pemberian imunisasi maka akan memberikan respons yang positif yaitu meningkatkan kemauan ibu untuk memberikan imunisasi dasar pada bayi. Pengetahuan yang cukup diharapkan dapat mempengaruhi tindakan seorang ibu dalam memberikan imunisasi secara lengkap kepada anaknya (Budiman dan Riyanti, 2014). Hal tersebut menunjukkan bahwa pengetahuan ibu mempengaruhi status imunisasi pada bayinya, dimana bayi yang mempunyai ibu 
dengan pengetahuan tentang imunisasi yang baik akan mempunyai status imunisasi dasar yang lengkap dibandingkan dengan bayi dengan ibu yang berpengetahuan kurang baik terhadap imunisasi.

Tabel 2 menunjukkan pengaruh sikap dengan kelengkapan imunisasi dasar bayi, bahwa tidak ada pengaruh sikap dengan kelengkapan imunisasi dasar bayi di Posyandu Balita Kalingga Banyuanyar Surakarta (0,595>0,05). Hasil ini mendukung penelitian terdahulu dari Prihanti, dkk (2016) bahwa sikap Ibu tidak mempengaruhi status kelengkapan imunisasi dasar pada bayi. Ibu bisa menyebabkan tidak adanya hubungan antara sikap dengan status imunisasi balita. Hal ini dikarenakan terkadang ibu tidak mengantarkan anaknya ke posyandu untuk diberikan imunisasi. Ada beberapa balita yang pergi ke posyandu diantarkan oleh pengasuh, nenek, bahkan ayah balita sendiri. Hal ini sesuai dengan pernyataan dari Azwar (2013) bahwa proses terjadinya sikap karena adanya rangsangan seperti pengetahuan masyarakat. Rangsangan tersebut menstimulus masyarakat untuk memberi respon berupa sikap positif maupun sikap negatif yang pada akhirnya akan diwujudkan dalam bentuk tindakan yang nyata. Hasil penelitian menunjukkan bahwa responden yang mempunyai anak dengan status imunisasi tidak lengkap yang paling banyak merupakan masyarakat dengan sosiobudaya atau keyakinan yang menganggap bahwa imunisasi itu haram/tidak boleh diberikan pada bayi, menganggap imunisasi dapat mengakibatkan anak demam, dan tidak menyetujui bahwa imunisasi tersebut sangat penting bagi anak, padahal seperti yang diketahui bahwa imunisasi tersebut sangat penting untuk anak. Efek demam yang dirasakan oleh anak merupakan efek sementara dari imunisasi tersebut karena pengaruh dari vaksin imunisasi yang dimasukkan ketubuh anak, begitu juga dengan anggapan haramnya imunisasi, karena vaksin yang diberikan pada waktu imunisasi tidak dilarang dalam agama. Responden dengan sosiobudaya atau keyakinan tersebut cenderung mempunyai sikap negatif terhadap imunisasi, sehingga banyak anak yang tidak mendapatkan imunisasi dasar lengkap (Triana, 2015). Berdasarkan hasil penelitian ini dapat diketahui bahwa perbedaan sikap yang dimiliki ibu tidak memiliki pengaruh signifikan dengan pemberian imunisasi dasar lengkap pada bayi, artinya bahwa ibu dengan sikap baik ataupun tidak baik mempunyai peluang lebih besar untuk memiliki perilaku yang sama yaitu tidak lengkap dalam pemberian imunisasi dasar pada balita. 
Tabel 2 menunjukkan pengaruh motivasi dengan kelengkapan imunisasi dasar bayi, bahwa ada pengaruh motivasi dengan kelengkapan imunisasi dasar bayi di Posyandu Balita Kalingga Banyuanyar Surakarta $(0,046<0,05)$. Hasil penelitian ini mendukung penelitian dari Triana (2015) bahwa motivasi berhubungan dengan pemberian imunisasi dasar lengkap pada bayi. Hal ini menunjukkan bahwa ibu yang memiliki motivasi baik maka ibu cenderung patuh terhadap pemberian imunisasi dasar lengkap. Orang tua yang kurang memahami efek imunisasi maka motivasinya juga rendah dan lebih memilih untuk tidak mengimunisasi. Sering kali orang tua merasa jera dengan efek samping dari imunisasi berupa demam, sedangkan demam karena efek samping bisa selesai dengan memberikan obat penurun demam. Salahnya informasi juga menimbulkan orang tua tidak melengkapi imunisasi pada bayinya (Kubli et al. 2017).

\section{Kesimpulan}

Ada pengaruh pengetahuan dan motivasi dengan kelengkapan imunisasi dasar bayi. Tidak ada pengaruh pekerjaan, pendidikan, sikap dengan kelengkapan imunisasi dasar bayi. Faktor yang paling berpengaruh adalah motivasi, berarti bahwa ibu yang mempunyai motivasi baik memiliki kemungkinan 20,091 lebih besar untuk melakukan imunisasi dasar bayi secara lengkap dibandingkan dengan ibu yang memiliki motivasi tidak baik. Sarannya yaitu hendaknya ibu lebih meningkatkan pengetahuan tentang pentingnya imunisasi melalui media cetak dan media elektronik serta lebih mengedepankan sikap yang baik tentang imunisasi karena imunisasi sangat penting dalam menjaga kondisi kesehatan bayi.

\section{Daftar pustaka}

Azwar, S (2013). Sikap Manusia. Yogyakarta : Pustaka Belajar.

Budiman dan Riyanto, A (2014). Kapita Selekta Kuisioner Pengetahuan dan Sikap Dalam Penelitian Kesehatan. Jakarta: Salemba Medika.

Hilda (2017). Hubungan Pengetahuan Dan Sikap Ibu Terhadap Motivasi Ibu Membawa Anak Imunisasi Polio Di Nagari Sungayang. IJONHS Vol 3 No 2, hal 37-41.

Istriyati, E (2011). Faktor-Faktor Yang Berhubungan Dengan Kelengkapan Imunisasi Dasar Pada Bayi Di Desa Kumpulrejo Kecamatan Argomulyo Kota Salatiga. 
Kementrian Kesehatan RI (2017). Bersama tingkatkan Cakupan Imunisasi, Menjaga Anak Tetap Sehat.

Kementrian Kesehatan RI (2018). Berikan Anak Imunisasi Rutin Lengkap.

Kubli, K. et al (2017). Student pharmacists 'perceptions of immunizations. Currents in Pharmacy Teaching and Learning, pp.1-7.

Mulyani, Shafira, N.N.A, Haris, A (2018). Pengetahuan Ibu Tentang Kelengkapan Imunisasi Dasar Bayi. Volume 6 No.1.

Notoatmodjo, S (2014). Kesehatan Masyarakat Ilmu dan Seni. Jakarta: Rineka Cipta.

Prihanti, GS, Rahayu, MP., Abdullah, MN (2016). Faktor-Faktor yang Mempengaruhi Status Kelengkapan Imunisasi Dasar Diwilayah Kerja Puskesmas X Kota Kediri. Jurnal Ilmi Kesehatan. Vol 12 No 2, hal 120-128.

Rahmawati, AI dan Umbul, CW (2014). Faktor Yang Mempengaruhi Kelengkapan Imunisasi Dasar Di Kelurahan Krembangan Utara. Jurnal Berkala Epidemiologi, Vol 2 No 1, hlm. 59-70.

Scobie, H. M., Ray, A., Routray, S., Bose, A., Bahl, S., Sosler, S., Anand, A. (2015). Cluster survey evaluation of a measles vaccination campaign in Jharkhand, India, 2012. Public Library of Science Journal, 10(5), 1-15. https://doi.org/10.1371/journal.pone.0127105

Triana, V (2015). Faktor yang Berhubungan Dengan Pemberian Imunisasi Dasar Lengkap Pada Bayi Tahun 2015. Jurnal Kesehatan Masyarakat Andalas. Vol 10 No 2, hal. 23-135.

WHO (2018). Cakupan Imunisasi dasar

Zuriatina, CN., Rahayu., Hiswani (2016). Faktor-Faktor yang Berhubungan dengan Kelengkapan Imunisasi Dasar pada Batita di Desa Hutaimbaru Kecamatan Halongonan Kabupaten Padang Lawas Utara Tahun 2016. Medan : Fakultas Kesehatan Masyarakat Universitas Sumatera Utara 